\title{
The origins of mural painting in Ancient Peru: archaeometric preliminary study of the Ventarrón mural paintings, Valle de Lambayeque
}

\author{
Véronique Wright ${ }^{1}$, Ignacio Alva Meneses ${ }^{2^{*}}$ and Éric Laval ${ }^{3^{*}}$
}

\begin{abstract}
Background: Since 2007, the research led on the Huaca Ventarrón site has allowed investigators to discover outstanding wall paintings. These murals are one of the oldest examples of this artistic expression in the Andean area and American continent (4000 BP). Analyses have given indications on the materials and techniques used by the first painters, ancestors of a long pictorial tradition.

Results: Thanks to an archaeometric approach, combining observations and analysis (Optical Microscopy (OM), Scanning Electron Microscopy and Energy-dispersive X-ray Spectroscopy (SEM-EDS), X-ray Fluorescence (XRF) and Fourier Transform Infrared Spectroscopy (FTIR)), it was possible to characterize the colorant materials used in the two constructive sampled phases. These materials are mineral pigments, iron oxides, clays and natural earth, mixed in order to create a wide chromatic scale.

Conclusions: Through this research we were able to obtain the first analytical data concerning such ancient mural paintings. It was very useful to comprehend the emergence of this artistic expression in Peru. These results open new research perspectives as well about the origins of Prehispanic pictorial technology as about conservation of wallpaintings in earthen architecture.
\end{abstract}

Keywords: Pigment, Color technology, Mural painting, Archaeometry, Peru

\section{Background}

Archaeological research in the Cerro Ventarrón area began in 2007 and allowed to understand the characteristics of the origin and flourishing of the Lambayeque valley civilization in the Peruvian north coast (Fig. 1). The Ventarrón Temple or "Huaca Ventarrón", located at the basis of a hill equally named and built over a rocky foreland, was the core of a pristine ceremonial center. Its initial phase has been dated around 2300-2035 B.C. [1], and

\footnotetext{
*Correspondence: alvameneses@yahoo.es; eric.laval@culture.gouv.fr

2 Museo Tumbas Reales de Sipán, Proyecto Arqueológico Cerro Ventarrón, Lambayeque, Peru

${ }^{3}$ Centre de Recherche et de Restauration des Musées de France (C2RMF),

Palais du Louvre, Paris, France

Full list of author information is available at the end of the article
}

it presents one of the oldest wall painting examples in the Peruvian territory.

This temple was built in three phases, one on top of the other. Until today ten architectonic renovations have been identified. The oldest phase was built over a rocky promontory marking the sacred character of its beginning as well as the orientation and distribution of the architectonic design. The broad Lambayeque Valley and the Reque River were visually controlled from the top of the temple. In this high area was placed the first ritual fire. On a wall at the south side of the fire, a representation of two fishes face to face in high relief without polychromy was discovered.

The second architectonic phase (radiocarbon dated around 4000 B.P.) is the best preserved and the most representative of the site (Fig. 2). It shows a radical change in

\section{Chemistry Central}

(C) 2015 Wright et al. This article is distributed under the terms of the Creative Commons Attribution 4.0 International License (http://creativecommons.org/licenses/by/4.0/), which permits unrestricted use, distribution, and reproduction in any medium, provided you give appropriate credit to the original author(s) and the source, provide a link to the Creative Commons license, and indicate if changes were made. The Creative Commons Public Domain Dedication waiver (http://creativecommons.org/ publicdomain/zero/1.0/) applies to the data made available in this article, unless otherwise stated. 


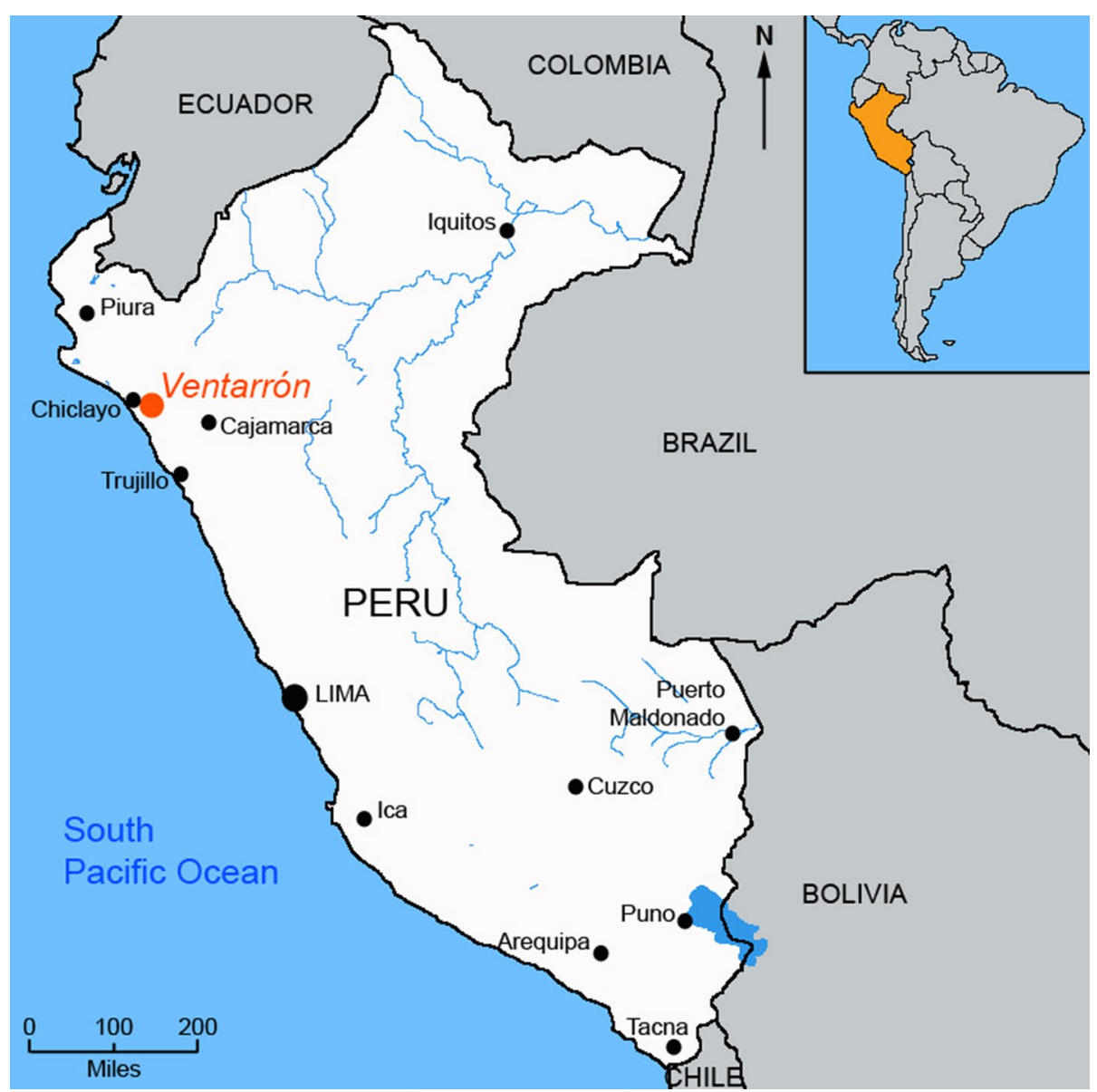

Fig. 1 Localization of Ventarrón site on the north coast of Peru

the architecture, materials and techniques, and marks the beginning of mural polychromy. During this phase was built the Red-White Temple, which is the most important and sacred area. The entire facade is decorated with broad oblique bands painted with white over red, while the double jamb access entrance is painted in black.

At the back part of the room, in the south wall, was placed a double sidewalk that was probably used as an altar. At each side of the sidewalk there are two polychrome murals, made with a wide chromatic range: vanished red in many tones from dark red almost brown to pink, yellow, white, black and gray. These paintings represent an original and exceptional iconography compared with the early Peruvian cultural traditions: the "deer in red" thematic (Fig. 3). Both paintings can be understood as net frames where three animals are caught. The quadrupeds in black can hardly be distinguished. They have a wavy gray color band that marks them from the neck to the back leg giving an idea of movement. Their flexed legs have a white line that marks the hoof, and their head have a big eye, snout, square herbivorous teeth and rhombus shaped ears. Their raised tail is traced with a white curve. The representation of deer caught in nets seems to be an essential theme in the first societies' ideology, which consecrated the ancient hunting and fauna.

On the southwest sector of the temple, there are remains of paint left on the eastern wall. This painting has a red background, a gray frame and two white vertical strips. Furthermore, a hall was built in the first room of this area with a singular cruciform plan. It is similar to the classic Andean cross or "chacana" with wall paintings in white, black, gray, red and yellow.

Finally, in order to build the third phase, which was called Green Temple, the inside of the Red-White Temple was completely filled. Vertically a retaining wall was built above the platform, slightly retracted from the previous facade and supported by a great buttress system. Over the atrium was built a new central room, which exterior walls were painted with green and white strips (Fig. 2). 


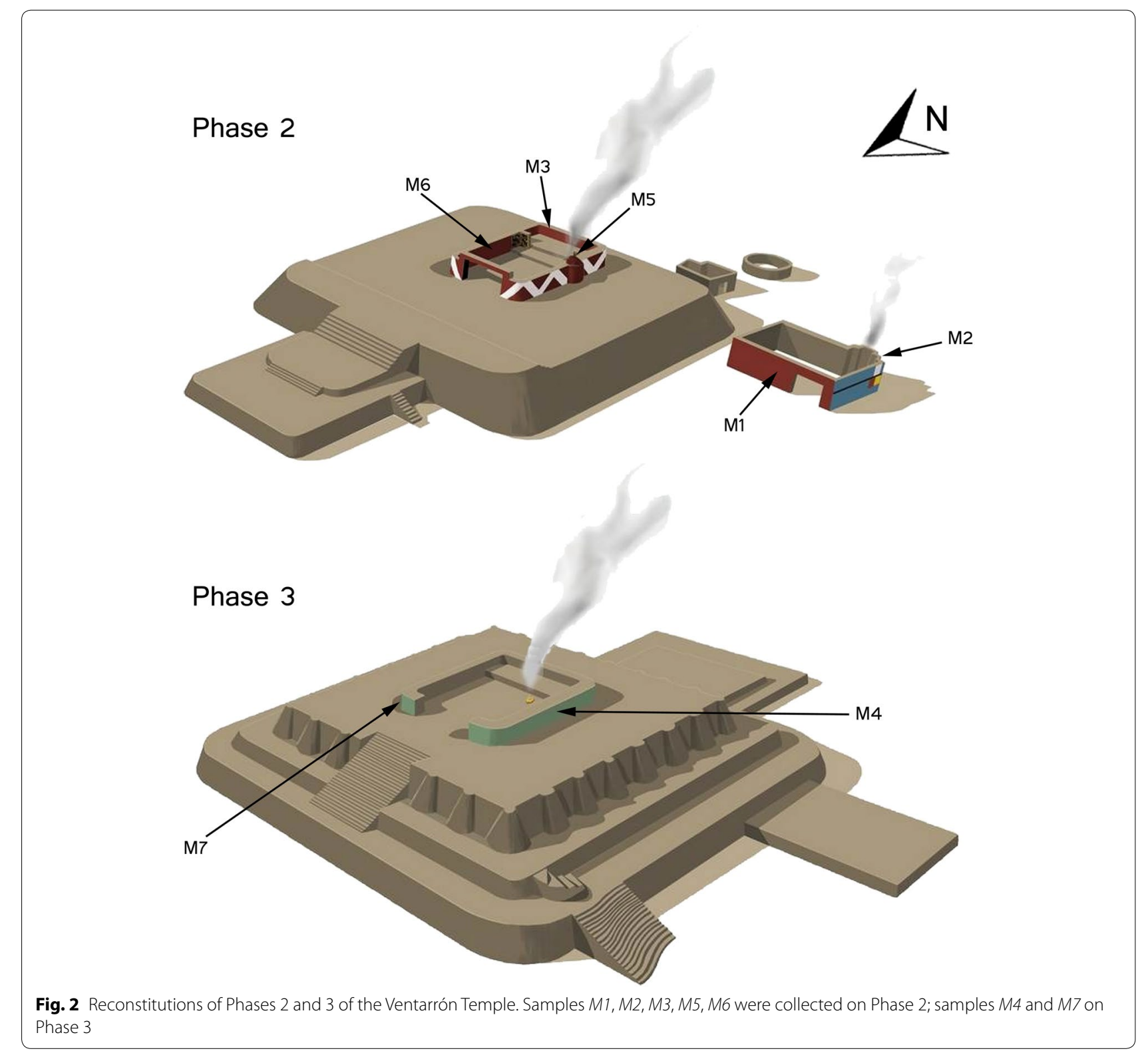

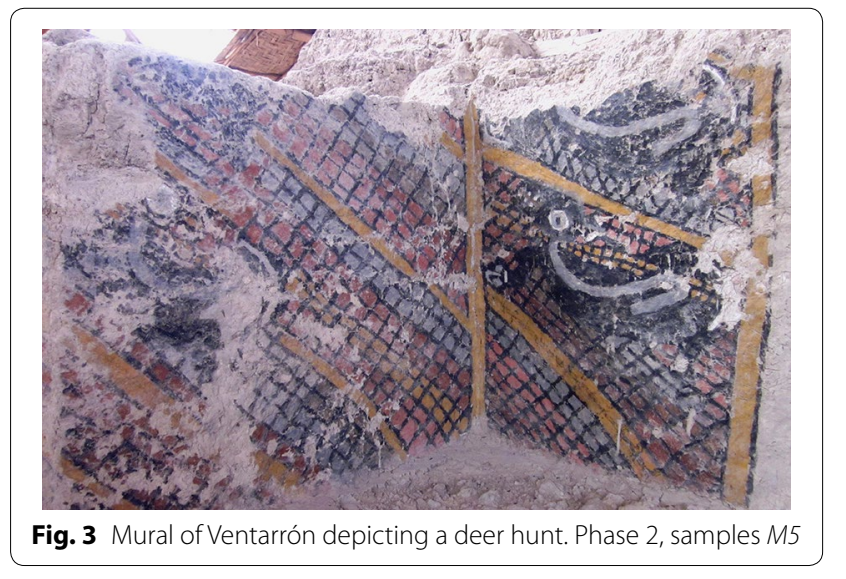

While the wall painting in Ventarrón has already been investigated from an iconographic point of view, in this research the approach will be archaeometric. The objective of this analytical methodology is to characterize the materials and techniques used by the artisan painters of this site, and then to rebuild the "chaîne opératoire" or pictorial technology from the extraction of the raw colouring materials until the finished mural. Besides Ventarrón being the oldest example of wall painting in the present Peruvian territory, this study will allow us to understand the origins of this artistic expression and the emergence of the artisanal practices developed later through the Prehispanic history. 


\begin{tabular}{|c|c|c|c|c|c|c|}
\hline Phase & Localization & Code & Color & $\begin{array}{c}\text { Microssopical Observations } \\
\text { (OM and/or SEM-EDX) }\end{array}$ & $\begin{array}{c}\begin{array}{c}\text { Elemental Composition (XRF) } \\
\text { (PUCP Laboratory) }\end{array} \\
\end{array}$ & Structural Composition (FTIR) \\
\hline \multirow{8}{*}{2} & \multirow{3}{*}{$\begin{array}{l}\text { Red-White Temple } \\
\text { Perimeter Wall }\end{array}$} & \multirow{2}{*}{ M3 } & Red & & $\begin{array}{l}\mathrm{Fe}^{*+}+\mathrm{Ca}, \mathrm{Mn}, \mathrm{Al}, \mathrm{Si}, \mathrm{S}, \mathrm{K}, \mathrm{Ti}, \mathrm{Mn} \\
+\mathrm{Ni}, \mathrm{Cu}, \mathrm{Zn}, \mathrm{As}, \mathrm{Sr}, \mathrm{Zr}, \mathrm{Y}, \mathrm{Rb} b^{* *} \\
\end{array}$ & \\
\hline & & & White & & $\begin{array}{c}\mathrm{Ca}^{*}+\mathrm{Fe}, \mathrm{Al}, \mathrm{Si}, \mathrm{S}, \mathrm{K}, \mathrm{Ti}, \mathrm{Mn} \\
+\mathrm{Ni}, \mathrm{Cu}, \mathrm{Zn}, \mathrm{As}, \mathrm{Sr}, \mathrm{Zr}, \mathrm{Y}, \mathrm{Rb}{ }^{* *} \\
\end{array}$ & \\
\hline & & M6 & Red & & $\begin{array}{r}\mathrm{Fe}^{*}+\mathrm{Ca}, \mathrm{Mn}, \mathrm{Al}, \mathrm{Si}, \mathrm{S}, \mathrm{K}, \mathrm{Ti} \\
+\mathrm{Ni}, \mathrm{Cu}, \mathrm{Zn}, \mathrm{As}, \mathrm{Sr}, \mathrm{Zr}, \mathrm{Y}, \mathrm{Rb}{ }^{* *} \\
\end{array}$ & $\begin{array}{l}\text { Hematite, Illite } \\
\text { + Smectite? }\end{array}$ \\
\hline & \multirow{5}{*}{$\begin{array}{c}\text { Red-White Temple } \\
\text { Deer Hunting Mural }\end{array}$} & \multirow{5}{*}{ M5 } & Red & 1 red layer $(30 \mu \mathrm{m})$ & $\begin{array}{r}\mathrm{Fe}^{*}+\mathrm{Ca}, \mathrm{Al}, \mathrm{Si}, \mathrm{S}, \mathrm{K}, \mathrm{Ti}, \mathrm{Mn} \\
+\mathrm{Ni}, \mathrm{Cu}, \mathrm{Zn}, \mathrm{As}, \mathrm{Sr}, \mathrm{Zr}, \mathrm{Y}, \mathrm{Rb}^{* *} \\
\end{array}$ & \\
\hline & & & White & 1 white layer $(50-300 \mu \mathrm{m})$ & $\begin{array}{r}\mathrm{Ca}^{*}+\mathrm{Fe}, \mathrm{Al}, \mathrm{Si}, \mathrm{S}, \mathrm{K}, \mathrm{Ti}, \mathrm{Mn} \\
+\mathrm{Ni}, \mathrm{Cu}, \mathrm{Zn}, \mathrm{As}, \mathrm{Sr}, \mathrm{Zr}, \mathrm{Y}, \mathrm{Rb}^{* *} \\
\end{array}$ & \\
\hline & & & Yellow & 1 yellow layer $(50 \mu \mathrm{m})$ & $\begin{aligned} & \mathrm{Fe}^{*}+\mathrm{Ca}, \mathrm{Al}, \mathrm{Si}, \mathrm{S}, \mathrm{K}, \mathrm{Ti}, \mathrm{Mn} \\
+ & \mathrm{Ni}, \mathrm{Cu}, \mathrm{Zn}, \mathrm{As}, \mathrm{Sr}, \mathrm{Zr}, \mathrm{Y}, \mathrm{Rb}^{* *}\end{aligned}$ & \\
\hline & & & Black & 1 black layer $(20 \mu \mathrm{m})$ & $\begin{array}{c}\mathrm{Fe}, \mathrm{Ca}^{*}+\mathrm{Al}, \mathrm{Si}, \mathrm{S}, \mathrm{K}, \mathrm{Ti}, \mathrm{Mn} \\
+\mathrm{Ni}, \mathrm{Cu}, \mathrm{Zn}, \mathrm{As}, \mathrm{Sr}, \mathrm{Zr}, \mathrm{Y}, \mathrm{Ga}, \mathrm{Rb}{ }^{* *} \\
\end{array}$ & \\
\hline & & & Grey & $\begin{array}{l}2 \text { grey pictorial layers: } 1 \text { external }(20 \\
\mu \mathrm{m})+1 \text { below }(30 \mu \mathrm{m}) \text { separated by a } \\
\text { coating layer }(100-250 \mu \mathrm{m})\end{array}$ & $\begin{aligned} & \mathrm{Fe}, \mathrm{Ca}{ }^{*}+\mathrm{Al}, \mathrm{Si}, \mathrm{S}, \mathrm{K}, \mathrm{Ti}, \mathrm{Mn} \\
&+\mathrm{Ni}, \mathrm{Cu}, \mathrm{Zn}, \mathrm{As}, \mathrm{Sr}, \mathrm{Zr}, \mathrm{Y}, \mathrm{Ga}, \mathrm{Rb}^{* *}\end{aligned}$ & \\
\hline \multirow{9}{*}{2} & \multirow{9}{*}{$\begin{array}{l}\text { Southeast sector } \\
\text { Lateral wing } \\
\text { "Chacana Room" }\end{array}$} & \multirow{4}{*}{ M1 } & Red & & $\begin{array}{r}\mathrm{Fe}, \mathrm{Ca} *+\mathrm{Al}, \mathrm{Si}, \mathrm{S}, \mathrm{K}, \mathrm{Ti}, \mathrm{Mn} \\
+\mathrm{Ni}, \mathrm{Cu}, \mathrm{Zn}, \mathrm{As}, \mathrm{Sr}, \mathrm{Zr}, \mathrm{Y}, \mathrm{Rb}^{* *} \\
\end{array}$ & \\
\hline & & & White & & $\begin{array}{r}\mathrm{Ca}, \mathrm{Fe} *+\mathrm{Al}, \mathrm{Si}, \mathrm{S}, \mathrm{K}, \mathrm{Ti}, \mathrm{Mn} \\
+\mathrm{Ni}, \mathrm{Cu}, \mathrm{Zn}, \mathrm{As}, \mathrm{Sr}, \mathrm{Zr}, \mathrm{Y}, \mathrm{Rb}^{* *} \\
\end{array}$ & Calcite, Illite \\
\hline & & & Black & 1 black layer $(30 \mu \mathrm{m})$ & $\begin{array}{c}\mathrm{Fe}, \mathrm{Ca}{ }^{*}+\mathrm{Al}, \mathrm{Si}, \mathrm{S}, \mathrm{K}, \mathrm{Ti}, \mathrm{Mn} \\
+\mathrm{Ni}, \mathrm{Cu}, \mathrm{Zn}, \mathrm{As}, \mathrm{Sr}, \mathrm{Zr}, \mathrm{Y}, \mathrm{Ga}, \mathrm{Rb}^{* *} \\
\end{array}$ & \\
\hline & & & Grey & & $\begin{array}{c}\mathrm{Fe}^{*}+\mathrm{Ca}, \mathrm{Al}, \mathrm{Si}, \mathrm{S}, \mathrm{K}, \mathrm{Ti}, \mathrm{Mn} \\
+\mathrm{Ni}, \mathrm{Cu}, \mathrm{Zn}, \mathrm{As}, \mathrm{Sr}, \mathrm{Zr}, \mathrm{Y}, \mathrm{Rb} * * \\
\end{array}$ & \\
\hline & & \multirow{5}{*}{ M2 } & Red & 1 red layer $(20 \mu \mathrm{m})$ & $\begin{array}{r}\mathrm{Fe}^{*}+\mathrm{Ca}, \mathrm{Mn}, \mathrm{Al}, \mathrm{Si}, \mathrm{S}, \mathrm{K}, \mathrm{Ti} \\
+\mathrm{Ni}, \mathrm{Cu}, \mathrm{Zn}, \mathrm{As}, \mathrm{Sr}, \mathrm{Zr}, \mathrm{Y}, \mathrm{Rb}^{* *} \\
\end{array}$ & $\begin{array}{l}\text { Hematite, Illite } \\
\text { + Smectite? }\end{array}$ \\
\hline & & & White & 1 white layer $(30 \mu \mathrm{m})$ & $\begin{array}{r}\mathrm{Ca}, \mathrm{Fe} *+\mathrm{Al}, \mathrm{Si}, \mathrm{S}, \mathrm{K}, \mathrm{Ti}, \mathrm{Mn} \\
+\mathrm{Ni}, \mathrm{Cu}, \mathrm{Zn}, \mathrm{As}, \mathrm{Sr}, \mathrm{Zr}, \mathrm{Y}, \mathrm{Rb}^{* *} \\
\end{array}$ & \\
\hline & & & Yellow & $\begin{array}{l}2 \text { pictorial layers: } 1 \text { external yellow layer } \\
(35 \mu \mathrm{\mu m})+1 \text { black layer below }(30 \mu \mathrm{m}) \\
\text { Separated by a coating layer }(230 \mu \mathrm{mm})\end{array}$ & $\begin{aligned} & \mathrm{Fe}^{*}+\mathrm{Ca}, \mathrm{Mn}, \mathrm{Al}, \mathrm{Si}, \mathrm{S}, \mathrm{K}, \mathrm{Ti} \\
+ & \mathrm{Ni}, \mathrm{Cu}, \mathrm{Zn}, \mathrm{As}, \mathrm{Sr}, \mathrm{Zr}, \mathrm{Y}, \mathrm{Rb} * *\end{aligned}$ & $\begin{array}{l}\text { Goethite, Illite } \\
\text { + Smectite ? }\end{array}$ \\
\hline & & & Black & 1 black layer $(35-50 \mu \mathrm{m})$ & $\begin{array}{c}\mathrm{Fe}^{*}+\mathrm{Ca}, \mathrm{Mn}, \mathrm{Al}, \mathrm{Si}, \mathrm{S}, \mathrm{K}, \mathrm{Ti} \\
+\mathrm{Ni}, \mathrm{Cu}, \mathrm{Zn}, \mathrm{As}, \mathrm{Sr}, \mathrm{Zr}, \mathrm{Y}, \mathrm{Rb}{ }^{* *} \\
\end{array}$ & $\begin{array}{ll}\text { Illite } \\
+? \\
?\end{array}$ \\
\hline & & & Grey & & $\begin{array}{l}\mathrm{Fe}^{*}+\mathrm{Ca}, \mathrm{Mn}, \mathrm{Al}, \mathrm{Si}, \mathrm{S}, \mathrm{K}, \mathrm{Ti}, \mathrm{Mn} \\
+\mathrm{Ni}, \mathrm{Cu}, \mathrm{Zn}, \mathrm{As}, \mathrm{Sr}, \mathrm{Zr}, \mathrm{Y}, \mathrm{Rb} * * \\
\end{array}$ & \\
\hline \multirow{3}{*}{3} & \multirow{3}{*}{$\begin{array}{l}\text { Main Temple } \\
\text { Perimeter Wall }\end{array}$} & \multirow{2}{*}{ M4 } & White & 1 white layer $(10-20 \mu \mathrm{m})$ & $\begin{array}{c}\mathrm{Ca}, \mathrm{Fe} *+\mathrm{Al}, \mathrm{Si}, \mathrm{S}, \mathrm{K}, \mathrm{Ti}, \mathrm{Mn} \\
+\mathrm{Ni}, \mathrm{Cu}, \mathrm{Zn}, \mathrm{As}, \mathrm{Sr}, \mathrm{Zr}, \mathrm{Y}, \mathrm{Rb} * * \\
\end{array}$ & Calcite, Illite \\
\hline & & & Green & & $\begin{array}{r}\mathrm{Fe}, \mathrm{Ca} *+\mathrm{K}, \mathrm{Al}, \mathrm{Si}, \mathrm{S}, \mathrm{Ti}, \mathrm{Mn} \\
+\mathrm{Ni}, \mathrm{Cu}, \mathrm{Zn}, \mathrm{As}, \mathrm{Sr}, \mathrm{Zr}, \mathrm{Y}, \mathrm{Rb}^{* *} \\
\end{array}$ & Green earth, Illite \\
\hline & & M7 & Green & 1 green layer $(25-30 \mu \mathrm{m})$ & $\begin{array}{c}\mathrm{Fe}, \mathrm{Ca}^{*}+\mathrm{K}, \mathrm{Al}, \mathrm{Si}, \mathrm{S}, \mathrm{Ti}, \mathrm{Mn} \\
+\mathrm{Ni}, \mathrm{Cu}, \mathrm{Zn}, \mathrm{As}, \mathrm{Sr}, \mathrm{Zr}, \mathrm{Y}, \mathrm{Rb} * *\end{array}$ & Green earth, Illite \\
\hline
\end{tabular}

Fig. 4 Table of the results of paint layers observations and analyses by OM, SEM-EDX, XRF and FTIR. *Main elements, **trace elements

\section{Methods}

In order to get a global vision of the pictorial technology developed in Ventarrón, we made samples of each color in each constructive phase (Fig. 2). With the archaeologists' and conservators' collaboration, seventeen samples were obtained from Phase 2, all belonged to the background colors: red, yellow, white, black and gray. Also three samples were extracted from Phase 3 of the two existing tones: white and green (Fig. 4). The samples recovered had an average size of $0.5 \mathrm{~cm}^{2}$, a necessary amount to apply the established experimental protocol.

First, samples were observed by stereomicroscopy. The selected ones were prepared in epoxy resin, cut in crosssections in order to be studied with optical microscopy $(\mathrm{OM})^{1}$ at 40 and 100 magnifications. This first step of observation allowed to get information about the number of pictorial layers, its set of features and its thickness. Then the 20 samples were analyzed with X-ray

\footnotetext{
1 The OM observations were proceeded at the Dating Laboratory of the "Universidad Nacional de Ingenieria" (UNI) in Lima, Peru.
}

fluorescence $(\mathrm{XRF})^{2}$. The data obtained allowed us to define the elemental composition of each pictorial layer and infer the chromogenic element in each sample. This analysis also enabled us to characterize trace elements, useful to the understanding of the geological origins of the minerals. After this, so as to complete and confirm all this data, a sample selection was analyzed with Fourier Transform Infrared Spectroscopy (FTIR) ${ }^{3}$. This

\footnotetext{
${ }^{2}$ Two XRF analysis series were done at:

The Archaeometry Laboratory, Faculty of Physics of the "Universidad Nacional Mayor de San Marcos" (UNMSM) in Lima by Dr. Jorge A. Bravo. The portable equipment used (model XR-100 CR) is composed of an X-ray tube (Eclipse II by AMPTEK-Oxford) with an Ag-anode, and an AMPTEK thermoelectrically cooled Si-PIN X-ray detector. Experimentations were realized in a $90^{\circ}$ configuration with the following parameters: $30 \mathrm{kV}-0.1 \mathrm{~mA}$. The Archaeology Laboratory of the "Pontificia Universidad Católica del Perú" (PUCP) in Lima. An equipment Bruker Tracer III-SD was used, with the following parameters: $45 \mathrm{kV}-11.30 \mu \mathrm{A}$.

${ }^{3}$ The FTIR analysis were proceeded at the "Centre de Recherche et de Restauration des Musées de France" (C2RMF), Palais du Louvre, Paris; with a Spectrometer FTIR Perkin Elmer Spectrum 2000, by mid-infrared transmission spectroscopy using a micro diamond cell.
} 


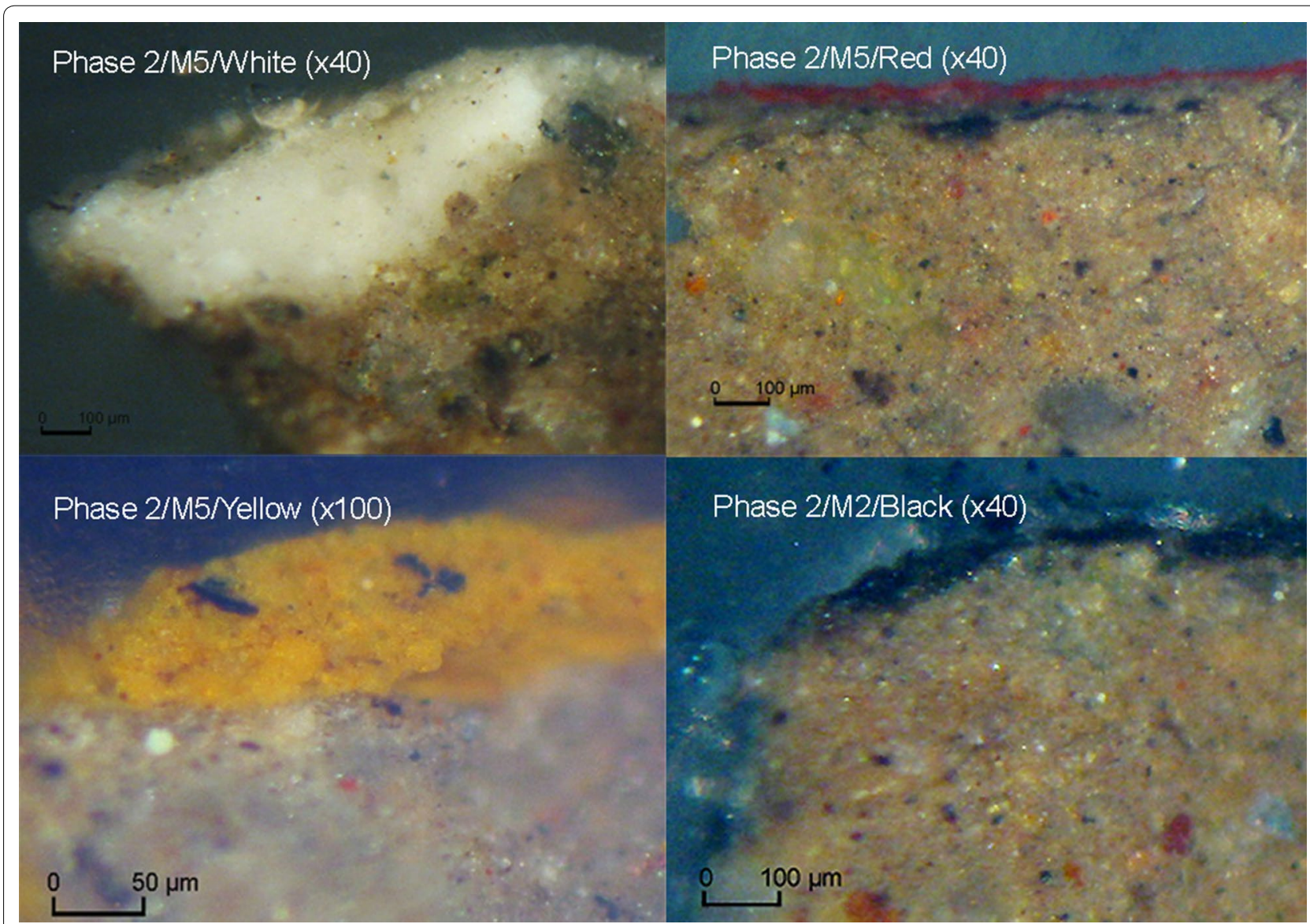

Fig. 5 Microscopic cross-sections of white, red, yellow M5 samples and black M2 sample from Phase 2

technique gave us structural information, useful to the identification of clays and natural earth often part of colorant mixtures composition. Finally, three samples (Phase 2/M2/Black, Phase 3/M4/White, Phase 3/M7/ Green), which identifications were not completely known, were observed and analyzed by Scanning Electron Microscopy and Energy-dispersive X-ray Spectroscopy (SEM-EDS) ${ }^{4}$.

Thanks to this protocol combining observation techniques and elemental and structural analysis, it was possible to answer to the problematic established about the wall painting in Ventarrón, and to achieve new results about materials and techniques used by the craftsmen.

\footnotetext{
${ }^{4}$ The SEM-EDS observations and analysis were proceeded at the "Centre de Recherche et de Restauration des Musées de France" (C2RMF), Palais du Louvre, Paris. The equipment used is a FEI XL30 CP associated with a Silicon Drift Detector X-MAX 50 anceladod an AZtec Energy Advanced analytic platform. The tension applied was $20 \mathrm{kV}$ in a controlled pressure (CP) configuration. The images were made combining secondary electrons (SE) (such as Everhart and Thornley detector) and back-scattered electrons (BSE).
}

\section{Results}

\section{Phase 2}

Most of the samples taken from Phase 2 had just one paint layer generally relatively thin $(35-50 \mu \mathrm{m}$ thick approximately, except the white M2 with a paint layer thickness ranging between 50 and $300 \mu \mathrm{m}$ ) (Fig. 5). The grain is very fine, about $5 \mu \mathrm{m}$ and homogenous. It was possible to notice that only one layer of paint was applied in this constructive phase. Only two samples have two pictorial layers, separated by a $200 \mu \mathrm{m}$ thick plaster layer (Phase 2/M5/Gray, Phase 2/M2/Yellow) as a result of being repainted.

The whole analyses achieved allowed to acquire information about each color composition (Fig. 4): the white is a mixture of calcite $\left(\mathrm{CaCO}_{3}\right)$ with a greenish clay, illite $\left(\left(\mathrm{K}, \mathrm{H}_{3} \mathrm{O}\right)(\mathrm{Al}, \mathrm{Mg}, \mathrm{Fe})_{2}(\mathrm{Si}, \mathrm{Al})_{4} \mathrm{O}_{10}\left[(\mathrm{OH})_{2},\left(\mathrm{H}_{2} \mathrm{O}\right)\right]\right) \quad$ (Fig. 6) [2]. The red and yellow chromogenic mineral belongs to an iron oxide (Fig. 7)-probably hematite $\left(\mathrm{Fe}_{2} \mathrm{O}_{3}\right)$ for red and goethite $(\mathrm{FeO}(\mathrm{OH}))$ for yellow according to the FTIR results-mixed with clay like illite. Should be noted the important concentration of calcium in both samples, registered with XRF analysis. The characterization of the 


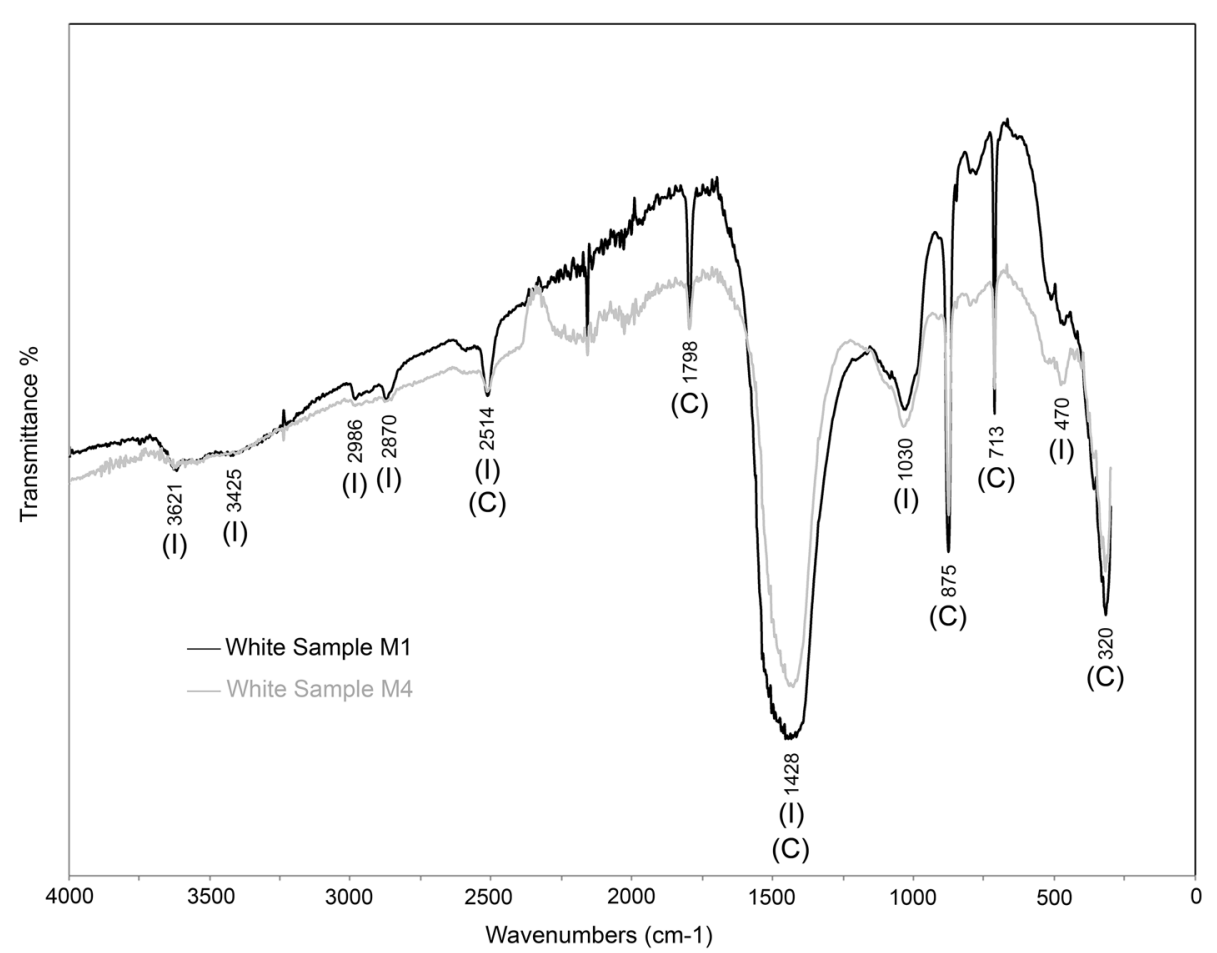

Fig. 6 FTIR spectra performed on the white samples M1 (Phase 2) and M4 (Phase 3). The absorption bands reveal the mix of illite (I) and calcite (C) responsible of the white tone

black pigment mixture was more problematic. Thanks to the XRF and SEM-EDS data we suggest that the chromogen element is iron mixed with clay of illite type (Figs. 4, 8). It was not possible to determine the structural composition of the iron oxide, but we propose as a hypothesis the use of magnetite $\left(\mathrm{Fe}_{3} \mathrm{O}_{4}\right)$. In addition, the SEM-EDS experimentations showed the presence of manganese in low concentration. Structural complementary analysis could enable to determine if this element constituted another chromogen component or belonged to the clay mineral environment. The compositions of the black and the gray layers are similar, so therefore it seems that they were made with the same materials.

Finally the XRF analyses have enabled to determine the presence of many trace elements as minor compounds which belong to metallic inclusions of nickel (Ni), copper $(\mathrm{Cu})$, zinc $(\mathrm{Zn})$ and arsenic (As) and rare earth element of yttrium (Y) in each sample (Fig. 7).

\section{Phase 3}

The results from the three samples taken from this phase, allowed us to demonstrate that the green and white paint represent just one very thin pictorial layer (from 10 to $30 \mu \mathrm{m}$ thickness), with thin homogenous grain (5 $\mu \mathrm{m}$ on average) just as Phase 2 (Fig. 4).
The white pigment is a mixture of calcite and illite. Its elemental and structural compositions are the same than the white elaborated in Phase 2 (Fig. 6). The elemental analysis revealed that the green mixture is composed of silicates with an important concentration of sodium, magnesium, aluminum, potassium and iron (Fig. 9). These results suggested that the green color is obtained with a green earth, a natural green pigment with low opacity. This postulate was confirmed by the FTIR analysis, showing presence of illite mixed with green earth, very probably glauconite (Fig. 10) which chemical composition is approximately $(\mathrm{K}, \mathrm{Na})$ $\left(\mathrm{Fe}^{3+}, \mathrm{Al}, \mathrm{Mg}\right)_{2}(\mathrm{Si}, \mathrm{Al})_{4} \mathrm{O}_{10}(\mathrm{OH})_{2}$ (with crystals of calcite, pyrite $\left(\mathrm{FeS}_{2}\right)$ and gypsum $\left(\mathrm{CaSO}_{4} \cdot 2 \mathrm{H}_{2} \mathrm{O}\right)$ that can be found as impurities) very similar to celadonite $\left(\mathrm{K}\left[\left(\mathrm{Al}, \mathrm{Fe}^{3+}\right),\left(\mathrm{Fe}^{2+}, \mathrm{Mg}\right)\right]\left(\mathrm{AlSi}_{3}, \mathrm{Si}_{4}\right) \mathrm{O}_{10}(\mathrm{OH})_{2}\right)[3]$.

Furthermore, similarly to Phase 2 , it was possible to demonstrate by XRF analysis the presence of many trace elements as minor elements which correspond to metallic inclusions of nickel $(\mathrm{Ni})$, copper $(\mathrm{Cu})$, zinc $(\mathrm{Zn})$ arsenic (As) and rare earth element of yttrium (Y) (Fig. 4).

\section{Discussion}

This archaeometric research allowed us to understand that all the coloring materials used in Ventarron's wall 


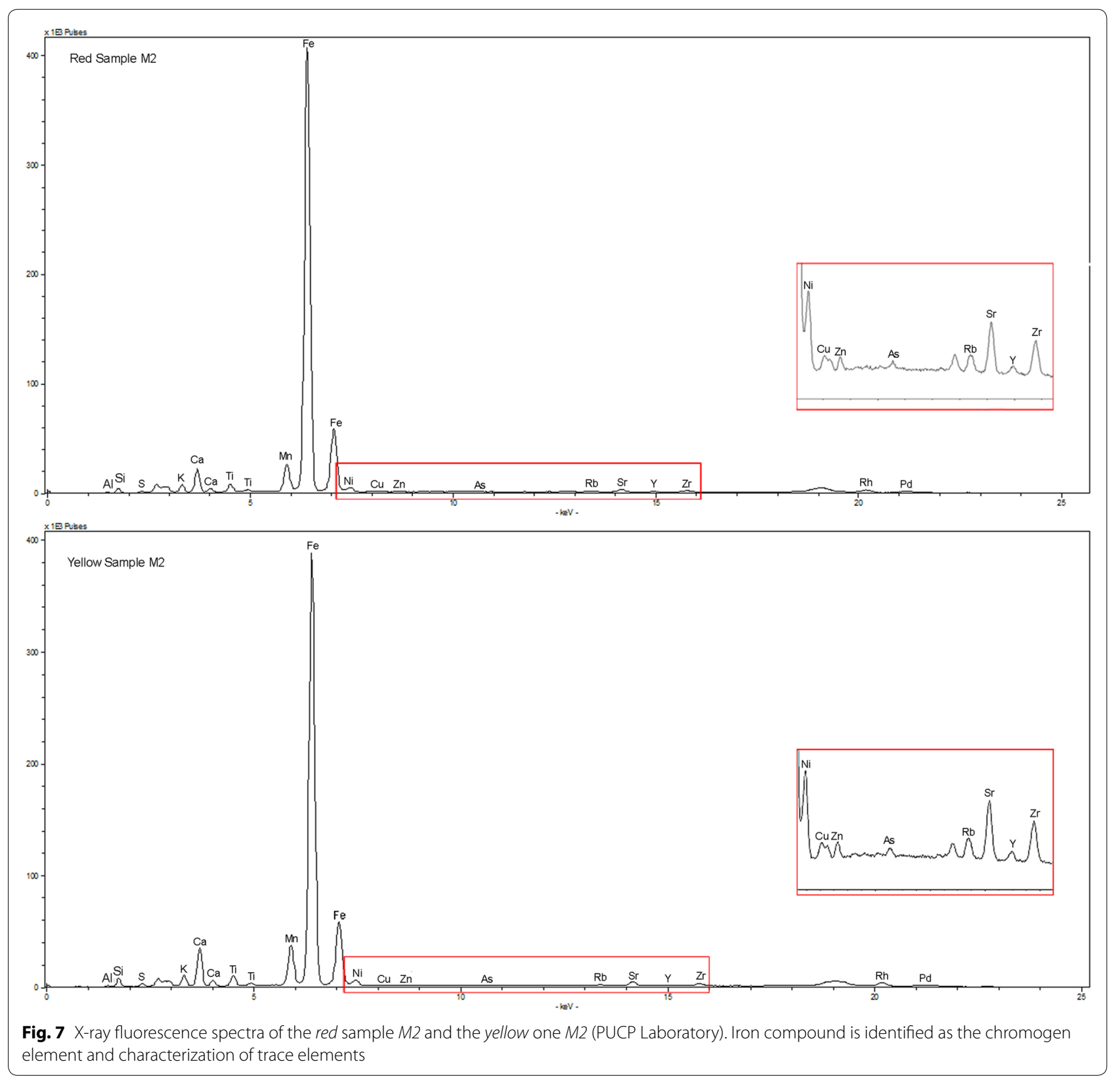

painting are natural pigments of mineral origin. The fineness and homogeneity of the granulometry indicate a carefully prepared work and a controlled technique. Furthermore, besides the two repainting identified, each constructive phase presents just one pictorial layer with thin thickness (10-35 $\mu \mathrm{m}$ average) which can be consider as a temporal indicator of the occupation of each building.

The results indicate the presence of illite and calcite in the white coloring mixture. The red and yellow chromogenic elements correspond to iron oxides such as the black-which structural complementary composition has to be completed-while the green belongs to green earth. All these are mixed with clay-illite-and associated to a high calcium concentration, possibly in calcite form. However, we can wonder if this association is intentional or fortuitous. In fact, calcite is usually used as additive for pigments due to its low colorant capacity, its opacity and its refractive index, which influences over the painting rheological properties, impermeability and conservation $[4,5]$. Moreover, previous researches, especially in the Moche art wall painting in the Peruvian 

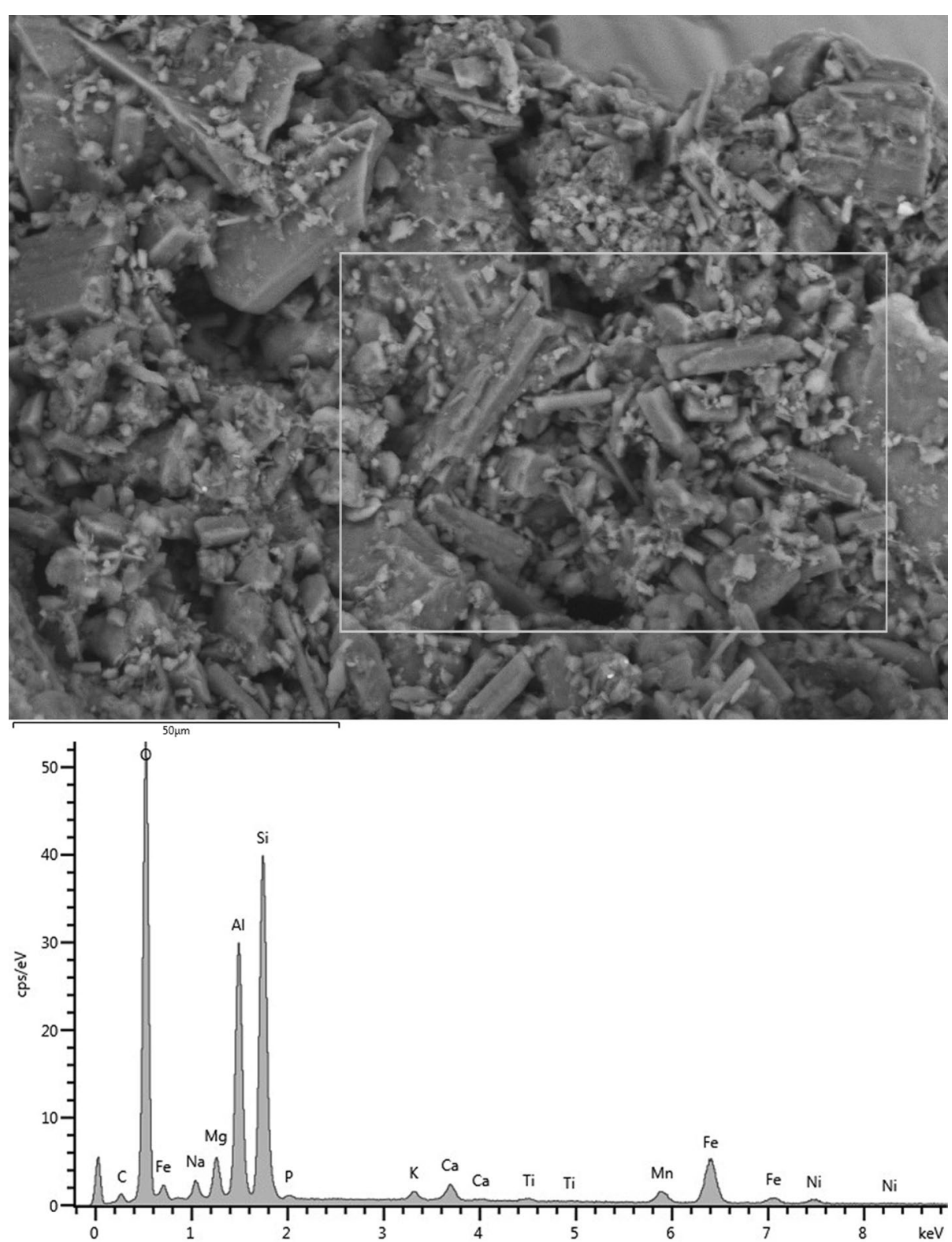

Fig. 8 SEM-EDS analysis of the black paint layer M2. BSE, $\times 800$

north coast $[6,7]$ suggest that the artisans mixed the white preparation to red, yellow and black preparations, in different and controlled proportions in order to get a wider chromatic range. Taking into account the chromatic palette used in Ventarrón we assume this mixture was intentional and had an esthetic and technical character.

On the other hand, the knowledge of pigments and additives leads us to wonder about the presence of organic binder, adjuvant usually added to the coloring mixture to improve the viscosity and adhesiveness to the wall surface. Nevertheless the experimentations realized, particularly in FTIR, did not allow to evidence this kind of product.

Regarding the interest of such preliminary data, new structural analysis (by FTIR or Raman spectroscopy for instance) should be done to precise the composition of the paint layers, the mineral structure of the iron oxides and green earth, such as the presence of organic materials.

Thanks to the XRF experimentations, it was possible to characterize the same trace elements in each sample. These minor compounds are considering as indicative 


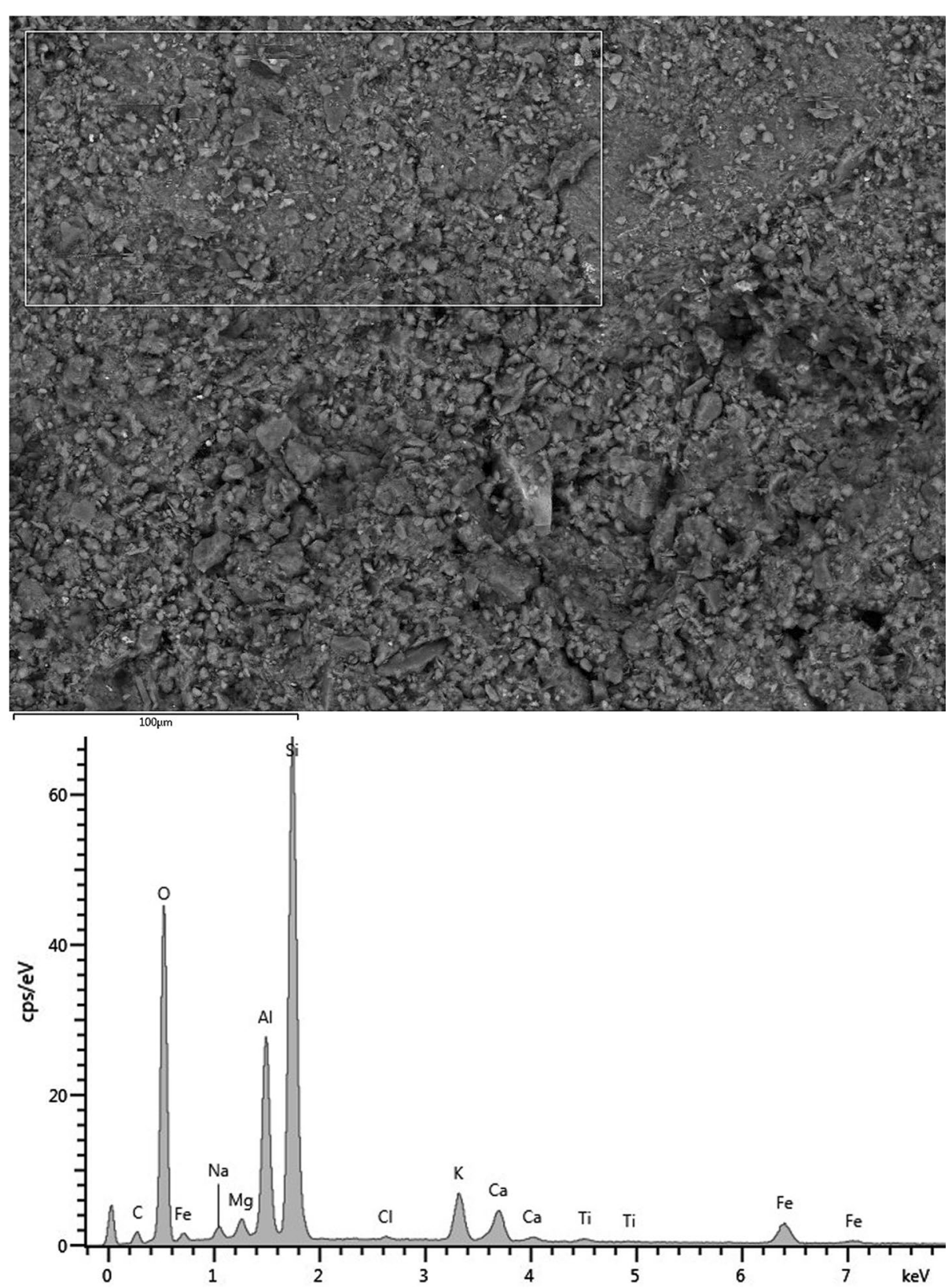

Fig. 9 SEM-EDS analysis of the green paint layer M7. BSE, $\times 350$

of the geological provenance of the raw materials. Being identical in each sample it might indicate a common origin (at least close) of the coloring materials. The presence of these markers as well as the similarity between the two white samples (Fig. 6) in the two constructive phases analyzed suggest a temporary continuity in the use of the materials and its geological origin.

This data proposes new research perspectives, particularly about quarry locations or veins of pigments used by the craftsmen.

\section{Conclusions}

The Ventarrón murals are one of the oldest wall painting examples in the Andean area and the American continent and this archaeometric study is the first one that has focused on such ancient polychrome vestiges, distinguishing the important nature of the conclusion reached.

The results contributed to identify the materials and techniques used since early periods. This information is useful to apprehend the emergence of this artistic expression and to better understand the first artisan painters, 


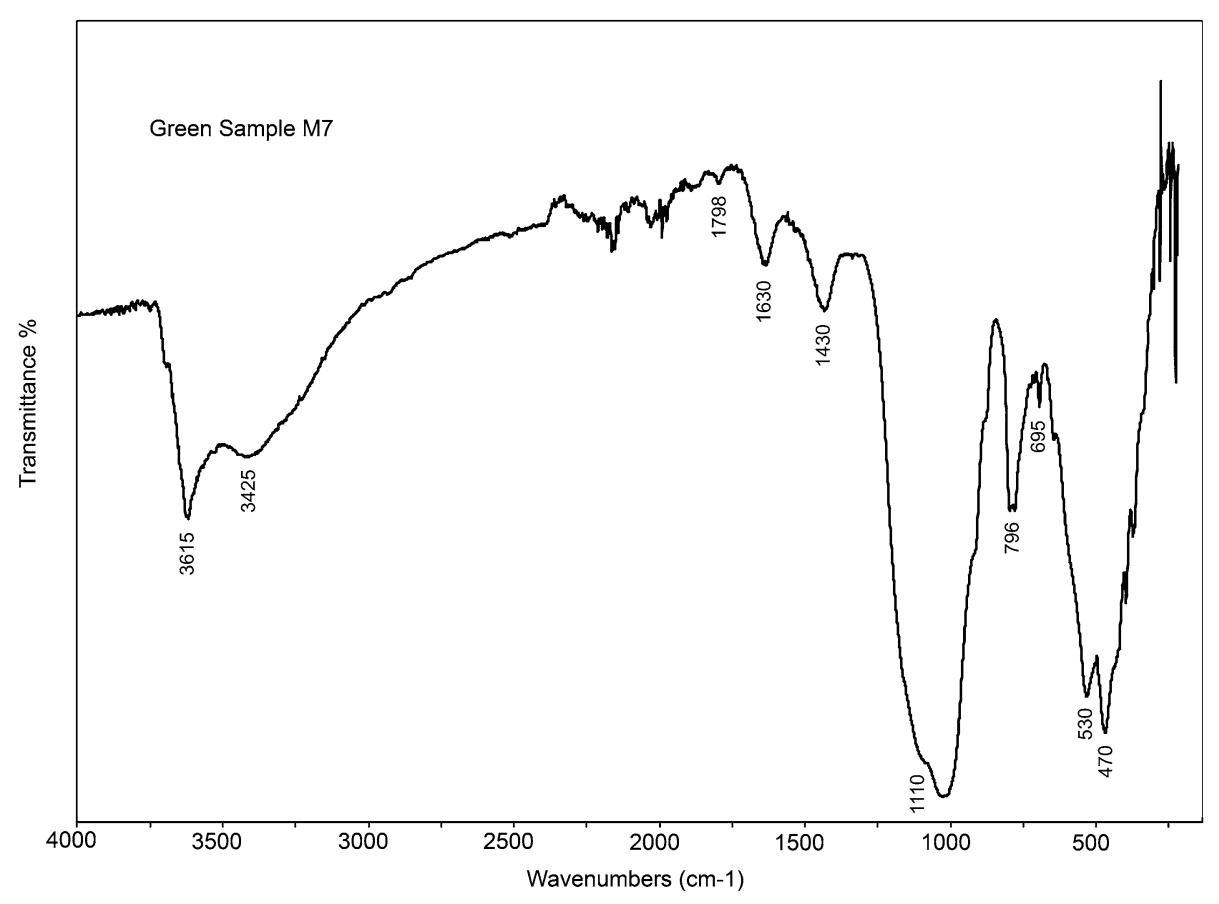

Fig. 10 FTIR spectrum performed on the green sample M7

ancestors of a long pictorial tradition developed up until the Spanish Conquest.

This kind of research also provides progress in conservation work. Indeed, according to the analyzed data, the treatments applied can be reevaluated and adapted, improving the murals protection conditions.

Finally, this research illustrates the interest and significance of archaeometry, arguing its systematization to develop archaeological problematic as well as heritage conservation issues in Peru.

\section{Authors' contributions}

VW and IAM coordinated the study. VW realized the observation protocol at the UNI, the XRF analysis at the PUCP and those by FTIR at the C2RMF. EL performed the analyses by SEM-EDX at the C2RMF. VW collected samples in Ventarrón assisted by IAM. VW edited and prepared the first version of the text. All authors read and approved the final manuscript.

\section{Author details}

${ }^{1}$ Institut Français d'Études Andines (IFEA), UMIFRE 17 MAEDI/CNRS USR 3337, Amérique Latine, Lima, Peru. ${ }^{2}$ Museo Tumbas Reales de Sipán, Proyecto Arqueológico Cerro Ventarrón, Lambayeque, Peru. ${ }^{3}$ Centre de Recherche et de Restauration des Musées de France (C2RMF), Palais du Louvre, Paris, France.

\section{Acknowledgements}

This research was possible thanks to the support of Dr. Luis Jaime Castillo, Vice-minister of Culture of Peru and director of the Archaeological laboratory of the PUCP in Lima, who kindly facilitated the access to the XRF equipment. We also thank Dr. Michel Menu, Director of the Research Department of the C2RMF in Paris, who allowed us to work in collaboration with this laboratory. Special thanks to the crew of Ventarrón for their kindness and hospitality; to Aldo Watanave for his help during the XRF measurements in PUCP; and to Gianella Pacheco and Charlotte Quinquis for their help editing this article.

\section{Compliance with ethical guidelines}

\section{Competing interests}

The authors declare that they have no competing interests.

Received: 5 December 2014 Accepted: 10 August 2015

Published online: 12 October 2015

\section{References}

1. Alva Meneses I (2008) Los complejos de Cerro Ventarrón y Collud-Zarpán: del Precerámico al Formativo en el valle de Lambayeque. Boletín de Arqueología PUCP 12:97-117

2. Du C, Zhou G, Deng J, Zhou J (2010) Characterization of soil clay minerals using mid-infrared spectroscopy. In: Xu J, Huang PM (eds) Molecular environmental soil science at the interfaces in the earth's critical zone. Springer, Heidelberg, pp 265-268

3. Aliatis I, Bersani D, Campani E, Casoli A, Paololottici P, Mantovan S, Marino I-G, Ospitali F (2009) Green pigments of the Pompeian artists' palette. Spectrochim Acta Part A Mol Biomol Spectrosc 73:532-538

4. Petit J, Roire J, Valot H (1995) Des liants et des couleurs pour servir aux artistes peintres et aux restaurateurs. EREC Éditeur

5. Vignaud C, Pomiès MP, Menu M (2000) La peinture préhistorique. Dossier pour la Science, vol 27, p 44

6. Wright V (2008) Étude de la polychromie des reliefs sur terre crue de la Huaca de la Luna Trujillo, Pérou. British Archaeological Reports (BAR S1808), Paris Monographs in American Archaeology 21, Archaeopress, Oxford

7. Wright V (2010) Pigmentos y tecnología artística mochica: una nueva aproximación en la comprensión de la organización social. Bulletin de I'Institut Français d'Études Andines (IFEA) 39-2:299-330 